\title{
Isolation of IL-2 Receptor- $\beta$ cDNA Clones from AtT-20 Pituitary Cells: Constitutive Expression and Role in Signal Transduction
}

\author{
John M. Petitto, M.D., Zhi Huang, M.D., Craig M. Rinker, B.S., and Denis B. McCarthy, B.S.
}

Interleukin-2 (IL-2) has been shown to stimulate ACTH secretion by anterior pituitary cells and has been implicated in pathophysiological processes of the pituitary and brain in several major neuropsychiatric disorders. The present study tested the hypothesis that IL-2 receptor- $\beta$ (IL-2R $\beta)$, a constitutively expressed and essential subunit for IL-2 signaling in lymphocytes, is expressed by AtT-20 pituitary cells and involved in transducing intracellular signals induced by IL-2. We isolated and sequenced three overlapping IL-2R $\beta$ cDNA clones from AtT-20 pituitary cells representing key regions of the gene protein coding sequence. These cDNA clones included conserved sequences shared by growth hormone and prolactin as well as intracy toplasmic Src and JAK family homology domains of nonreceptor protein tyrosine kinases essential for $I L-2$ signaling in lymphocytes. Their nucleotide sequences were $100 \%$ homologous with those expressed by lymphocytes (together they comprised $70 \%$ of the full length coding sequence). The IL-2R $\beta$ gene is constitutively expressed by AtT-20 pituitary cells, and its transcription was upregulated after CRF stimulation. Species-specific $I l-2$ induced intracellular signals in AtT-20 cells known to be mediated by $I l-2 R \beta$, including a transient increase in c-myc nuclear proto-oncogene transcription and the dose-dependent induction of DNA replication as measured by $\left[{ }^{3} H\right]$ thymidine incorporation. The IL-2-induced DNA replication signal was not delivered by heat inactivated IL-2 and was partially blocked by a murine anti-IL-2R $\beta$ monoclonal antibody. These studies suggest that $I L-2 R \beta$ may be a critical target involved in mediating the neuroimmunological actions of this prototypical cytokine in endocrine cells.

[Neuropsychopharmacology 17:57-66, 1997] (C) 1997 American College of Neuropsychopharmacology. Published by Elsevier Science Inc.

Lapchak 1994; Sauer et al. 1994; McAllister et al. 1995; Nimgaonkar et al. 1995). This prototypical immunoregulatory cytokine has a variety of actions in the central nervous and endocrine systems (for reviews, see Merrill 1990; Nistico and De Sarro 1991; Nistico 1993). IL-2 has been shown to modulate the physiology of the pituitary gland in both animals and humans. Alterations in $\mathrm{ACTH}$ and cortisol secretion, for example, are manifested by cancer patients receiving IL-2 immunotherapy (Lotze et al. 1985; Denicoff et al. 1989). IL-2 has also been shown to stimulate ACTH secretion from anterior pituitary corticotrophs in vivo and in vitro (Farrar 1984; Smith et al. 1989; Naito et al. 1989; Karanth and McCann 1991; Harbuz et al. 1992; Hanisch et al. 1994), and recent studies of invertebrates suggest the possibility 
that corticotrophin-releasing factor (CRF) and IL-2 share a common evolutionary origin (Ottaviani et al. 1994). Knowledge of the mechanisms by which IL-2 transduces intracellular signals in endocrine cells may have important implications for understanding pathophysiological processes of the HPA axis. Little is known, however, about the molecular characteristics of IL-2 receptors expressed by endocrine cells.

Lymphocyte IL-2 receptors (IL-2R) are comprised of a multisubunit receptor complex, where three distinct subunits, $\alpha, \beta$, and $\gamma$ combine via differential expression to form different functional IL-2R subtypes (for review, see Hatakeyama et al. 1989b; Minami et al. 1993; Taniguchi and Minami 1993). The constitutively expressed IL2R $\beta$ and IL2R $\gamma$ subunits form a so called "intermediate" affinity receptor $\left(K_{D} \cong 1 \mathrm{nmol} / \mathrm{L}\right)$. The IL2R $\beta$ and IL2R $\gamma$ subunits are critical for transducing IL-2 signaling processes in lymphocytes. Activated lymphocytes often co-express the accessory IL-2R $\alpha$ subunit, which together with IL2R $\beta$ and IL2R $\gamma$ form a "high" affinity receptor $\left(K_{D} \cong 10 \mathrm{pmol} / \mathrm{L}\right)$. By itself, IL-2R $\alpha$ can form a "low" affinity receptor $\left(\mathrm{K}_{\mathrm{D}} \cong 10 \mathrm{nmol} / \mathrm{L}\right)$, which is not capable of transducing IL-2 signals in lymphocytes. Whereas IL2R $\beta$ and IL2R $\gamma$ are members of the superfamily of cytokine receptors, IL-2R $\alpha$ is not (Bazan 1990; Taniguchi and Minami 1993). Recent molecular cloning studies by our laboratory indicate that IL2R $\beta$ and IL-2R $\alpha$ genes are expressed by normal murine brain cells (Petitto and Huang 1994, 1995) and IL2R $\beta$ and IL-2R $\alpha$ mRNA has been identified in the adult human brain tissue and fetal brain tissue, respectively (Otero and Merrill 1995). Forebrain IL-2 receptors appear to be the site of action of those neuroendocrine effects of IL-2 which are initiated at the level of the hypothalamus (Bindoni et al. 1988; Harbuz et al. 1992; Cambronero et al. 1992; Bartholomew and Hoffman 1993; Karanth et al. 1993; Lapchak and Araujo 1993; Hillhouse 1994; Raber and Bloom 1994; Raber et al. 1995).

Landmark studies demonstrated that IL-2 could induce ACTH secretion and proopiomelanocortin (POMC) gene expression from anterior pituitary cells (Farrar 1984; Brown et al. 1987; Smith et al. 1989). Detection of the $\alpha$-subunit of the IL-2 receptor, a nonconstitutively expressed accessory subunit of the IL-2 receptor heterotrimer complex, has been identified in AtT-20 pituitary cells (Smith et al. 1989; Arzt et al. 1992). Since the interleukin-2 receptor $\alpha$ accessory subunit (IL-2R $\alpha$ ) lacks an appreciable intracellular domain and is not involved in the intracellular signaling events in lymphocytes, it was unknown whether IL-2 signals in pituitary cells are transduced by the IL-2R $\beta$ subunit of the superfamily of cytokine receptors or by a unique subunit expressed by cells of endocrine origin (Merrill 1990; Arzt et al. 1992; Petitto and Huang 1995).

In the present study we therefore sought to test the hypotheses that IL-2R $\beta$ or an IL-2R $\beta$-like gene is consti- tutively expressed by AtT-20 pituitary cells and involved in IL-2-induced signal transduction processes in this endocrine cell line. In lymphocytes, two such processes induced by IL-2, which are known to be mediated by IL2R $\beta$, are c-myc nuclear proto-oncogene activation and growth signals (Hatakeyama et al. 1989a,b; Shibuya et al. 1992; Minami et al. 1993; Taniguchi and Minami 1993; Nelson et al. 1994; Taniguchi 1995). To test these hypotheses, the present study sought to determine specifically: (1) if AtT-20 pituitary cells express IL-2R $\beta$ mRNA; (2) whether key segments of the coding sequence of the IL-2R $\beta$ expressed by AtT- 20 cells, in particular regions of the intracellular domain where signaling sequences of the receptor reside, were derived from the same or a gene related to the lymphocyte IL$2 R \beta$; (3) if IL-2R $\beta$ was constitutively expressed by these pituitary corticotrophs, and upregulated after CRF stimulation; (4) whether species-specific recombinant IL-2 could activate intracellular pathways known to be associated with IL-2R $\beta$ in lymphocytes-increased transcription of c-myc nuclear proto-oncogene and the delivery of an intracellular DNA replication signal to AtT-20 cells and; (5) if the DNA replication signal induced by IL-2 could be blocked by a specific monoclonal antibody to the murine lymphocyte IL-2R $\beta$.

\section{MATERIALS AND METHODS}

\section{Reverse Transcription and Polymerase Chain Reaction (PCR)}

The mRNA used for PCR amplification and cloning experiments was isolated from the mouse anterior pituitary cell line, AtT-20 (American Type Culture Collection), using a commercial kit (Microfast Track, Invitrogen) as described previously (Petitto and Huang 1994; Petitto et al. 1994). The cDNA used for PCR amplification was synthesized using a $0.5 \mu \mathrm{g}$ of poly $(\mathrm{A})+$ mRNA primed with a mixture of $0.12 \mu \mathrm{g}$ oligo(dT) and $0.4 \mu \mathrm{g}$ of random primers. Reverse transcription was conducted with reverse transcriptase (cDNA Cycle, Invitrogen) for $1 \mathrm{~h}$ at $42^{\circ} \mathrm{C}$. After denaturation of RNA-cDNA hybrids at $95^{\circ} \mathrm{C}$ for $3 \mathrm{~min}$ and cooling on ice, additional reverse transcriptase (5 units) was added to the reaction mixture and reincubated for $1 \mathrm{~h}$ at $42^{\circ} \mathrm{C}$. The reaction mixture was heated again to $95^{\circ} \mathrm{C}$ for $3 \mathrm{~min}$ and cooled on ice.

PCR primers for IL-2R $\beta$ were designed with the computer assisted program PCRPLAN (Intelligenetics) using the published sequence of the mouse lymphocyte IL-2R $\beta$ (Kono et al. 1990). To determine if an IL-2Rß (or a sequence homologous to the lymphocyte IL-2RB) is expressed by AtT-20 pituitary cells, we designed primers to amplify the WSXWS sequence characteristic of the lymphocyte IL-2R $\beta$ and other members of the cytokine receptor superfamily (Bazan 1990; Taniguchi and Minami 1993). The upstream and downstream primers 
were 5'-GTGGACCTCCTTGACATA-3' and 5'-GTTTCGTTGAGCTTTGA-CCCTCA-3', respectively. Subsequent to the isolation of this $\mathrm{CDNA}$ clone, primers were then targeted to cytoplasmic domain sequences known to be essential for the signaling functions of IL- $2 R \beta$ in lymphocytes. The two pairs of primers used for those experiments were: 5'-GTGAGGGTCAAAGCTCAACG-3' and 5'GATCTCCAAGGCATTGGG-3', upstream and downstream primers, respectively, and; $5^{\prime}$-CCAGCTGCTTCACCAACCA- ${ }^{\prime}$ ' and 5'-GTAAGCCCATCAGGTCACG-3', upstream and downstream primers, respectively.

The upstream and downstream primers for murine c-myc were 5'-ATGTTGCGGTCGCTACGTC-3' and 5'-CTGTCCAACTTGGCCCTCTTG-3', respectively. The upstream and downstream primers for murine $\beta$-actin were $5^{\prime}$-GTGGGCCGCTCTAGGCACCAA- $3^{\prime}$ and $5^{\prime}$-CTCTTTGATGTCACGCACGATTTC-3', respectively. All primers were synthesized at DNA Synthesis Core of the University of Florida Interdisciplinary Biotechnology Center, except for the murine $\beta$-actin primers, which were purchased commercially (Clonetech).

PCR reactions were performed using a $50 \mu \mathrm{l}$ total reaction volume containing $0.4 \mu \mathrm{mol} / \mathrm{L}$ each of forward and reverse primers, $20-40 \mathrm{ng} \mathrm{cDNA}, 0.2 \mathrm{mmol} / \mathrm{L}$ of each dNTP, and 2.5 units Taq DNA polymerase (GIBCO BRL), in $50 \mathrm{mmol} / \mathrm{L} \mathrm{KCl} / 0.01 \%$ gelatin $/ 10$ $\mathrm{mmol} / \mathrm{L}$ Tris- $\mathrm{HCl}$ buffer with $2 \mathrm{mmol} / \mathrm{L} \mathrm{MgCl}_{2}$, and amplified using a thermal cycler with a heated evaporation cover (Ericomp). The cycling parameters were: denaturing $94^{\circ} \mathrm{C}(45 \mathrm{~s})$; annealing $56^{\circ} \mathrm{C}(30 \mathrm{~s}$, for IL-2R $\beta$ and $\beta$-actin, and $25 \mathrm{~s}$ for $\mathrm{c}$-myc); extension $72^{\circ} \mathrm{C}(2 \mathrm{~min})$ with a final extension step of $7 \mathrm{~min}$. Thirty-five cycles were used for the PCR cloning experiments. In other experiments, the identity of c-myc and $\beta$-actin bands were confirmed by size and by select restriction enzyme cuts.

\section{PCR Cloning of IL-2R $\beta$ from Mouse AtT-20 Pituitary Cells}

The PCR amplified IL-2R $\beta$ cDNA was cloned from the library of cDNAs obtained from mouse AtT-20 pituitary cells. Direct cloning of PCR products was performed by the T-A overhang method as described previously (Petitto et al. 1994; Petitto and Huang 1994, 1995). In brief, the PCR product was agarose gel purified. Agarose containing the band was removed by centrifugation in a spin-x column (Costar), the cDNA was purified further by phenol extraction and ethanol precipitation, washed with $75 \%$ ethanol, dried, and resuspended in TE buffer. The vector (pGEM-T, Promega) and PCR product of interest were ligated at $12^{\circ} \mathrm{C}$ overnight. The vector was then transformed into competent Escherichia coli, spread on LB plates containing ampicillin and X-Gal, and white colonies were selected after overnight incubation at $37^{\circ} \mathrm{C}$. Plasmid isolation and restriction analysis were performed using standard methods.

\section{DNA Sequencing}

The IL-2R $\beta$ cDNA clones isolated from AtT-20 pituitary cells were sequenced by the chain termination method (Sequenase 2.0, United States Biochemical) using ${ }^{35} \mathrm{~S}$ labeled nucleotides (Amersham). Three independent clones from each of the three different cDNAs amplified from AtT-20 pituitary cells were sequenced. Electrophoresis was performed using a $6 \%$ polyacrylamide sequencing gel.

\section{Ribonuclease Protection Assay}

The ribonuclease protection assay was performed as described previously (Petitto et al. 1994; Petitto and Huang 1994, 1995). Total RNA was isolated from homogenized tissue from AtT-20 pituitary cells by the guanidine isothiocyanate method. The uniform loading of equal quantities of RNA to each protection assay reaction was ensured by adjusting the amounts of RNA in the samples via $\mathrm{OD}_{260} \mathrm{~nm}$ absorbance using a spectrophotometer, and by subsequent comparison of the $28 \mathrm{~S}$ and $18 \mathrm{~S}$ rRNA bands obtained from an aliquot of the sample resolved on an ethidium bromide-stained gel (Ausubel et al. 1995).

A ${ }^{32} \mathrm{P}$-labeled antisense riboprobe was synthesized using the $\mathrm{T}_{7}$ promotor of the PCR ${ }^{\mathrm{TM}} \mathrm{II}$ vector (Invitrogen) containing a cloned brain IL-2R $\beta$ cDNA (Petitto and Huang 1994) according to standard methods. Briefly, $30 \mu \mathrm{g}$ of total RNA was co-precipitated with the riboprobe for $30 \mathrm{~min}$ at $-80^{\circ} \mathrm{C}$. The $\mathrm{mRNA} /$ probe precipitate was dried, resuspended in $20 \mu l$ hybridization buffer $(40 \mathrm{mmol} / \mathrm{L}$ Pipes $/ 1 \mathrm{mmol} / \mathrm{L}$ EDTA $/ 0.4 \mathrm{~mol} / \mathrm{L}$ $\mathrm{NaCl} / 80 \%$ formamide) and incubated at $80^{\circ} \mathrm{C}$ for 10 min. After brief centrifugation, the $\mathrm{mRNA} /$ probe was resuspended and incubated for $16 \mathrm{~h}$ at $47^{\circ} \mathrm{C}$. This was followed by incubation in RNase $\mathrm{A} / \mathrm{RN}$ ase $\mathrm{T}_{1}$ digestion buffer at $32^{\circ} \mathrm{C}$ for $45 \mathrm{~min}$, and incubated for $15 \mathrm{~min}$ at $37^{\circ} \mathrm{C}$ after the addition of SDS $(0.6 \%)$ and proteinase $\mathrm{K}$ $(0.03 \%)$. After phenol/choloform extraction, carrier RNA was added $(5 \mu \mathrm{g})$, and ethanol precipitation was performed at $-80^{\circ} \mathrm{C}$ for $30 \mathrm{~min}$. The pellet was washed and dried in ethanol, dissolved in $80 \%$ formamide dye, heated to $80^{\circ} \mathrm{C}$ for $7 \mathrm{~min}$, and cooled on ice for $1 \mathrm{~min}$. Samples were subsequently loaded on a $6 \%$ polyacrylamide gel. Autoradiograms were scanned using computer assisted densitometry (MCID System, Imaging Research, Inc.) and were quantified relative to the $28 \mathrm{~S}$ rRNA band.

\section{Cell Culture and Murine IL-2 Stimulation of Murine AtT-20 Pituitary Cells}

AtT-20 pituitary cells were cultured in Dulbecco's Modified Eagle's Medium (DMEM) with 10\% fetal calf serum, penicillin $(100 \mathrm{U} / \mathrm{ml})$, and streptomycin $(100 \mu \mathrm{g} /$ 
$\mathrm{ml})$ at $37^{\circ} \mathrm{C}$ in a humidified $\mathrm{CO}_{2}$ incubator $(90 \%$ air/ $10 \% \mathrm{CO}_{2}$ ). In some experiments, cells were stimulated with murine recombinant IL-2 (mIL-2) (Biosource International) to determine the effects of this cytokine on: (1) c-myc proto-oncogene induction and (2) cell proliferation. Murine IL-2-induced proliferation of AtT-20 pituitary cells was performed using a $\left[{ }^{3} \mathrm{H}\right]$ thymidine incorporation assay. Briefly, $10^{5}$ cells were initially subcultured in 6-well plates (Costar \#3506) containing only culture media. After $24 \mathrm{~h}$ of incubation, $100 \mu \mathrm{l} \mathrm{mIL-2}$ dissolved in media or $100 \mu \mathrm{l}$ media only (as control) was added to each culture well to yield a final volume of $1 \mathrm{ml}$. In experiments where an IL-2R $\beta$ monoclonal antibody was used to antagonize the functional effects of mIL-2, either the monoclonal antibody or media was added $2 \mathrm{~h}$ before the addition of $\mathrm{mIL}-2$. The cells were incubated in the presence or absence of mIL-2 for $48 \mathrm{~h}$, pulsed with $\left[{ }^{3} \mathrm{H}\right]$ thymidine $(4 \mu \mathrm{Ci} / \mathrm{ml}$; Amersham) for an additional $24 \mathrm{~h}$, and harvested onto glass-fiber filter paper using a cell harvester (Skatron). These experimental conditions, in particular the culture and pulsing times, were adopted based on the doubling time of this subline of AtT- 20 cell ( $\sim 5.5$ days) and on preliminary experiments. Results are expressed as the incorporation index (the ratio of $\left[{ }^{3} \mathrm{H}\right]$ thymidine incorporation in the presence of $\mathrm{mIL}-2 /\left[{ }^{3} \mathrm{H}\right]$ thymidine incorporation in the absence of mIL-2). Across all experiments, basal $\left[{ }^{3} \mathrm{H}\right]$ thymidine incorporation (in the absence of IL-2) ranged from $66-424 \mathrm{cpm} / \mu \mathrm{l}$.

One-way analysis of variance (ANOVA) was used to assess differences in IL-2-induced proliferation of AtT20 pituitary cells across conditions, with preplanned comparisons used to test for differences between select experimental conditions.

\section{RESULTS}

\section{Nucleotide Sequence of IL-2R $\beta$ cDNA Clones Isolated from AtT-20 Pituitary Cells}

Figure 1 shows the results of the initial PCR experiments to determine if AtT-20 pituitary cells express the IL-2R $\beta$ sequence containing the WSXWS motif found among members of the cytokine receptor superfamily. The expected size $341 \mathrm{bp}$ cDNA for IL-2R $\beta$ was amplified from splenic lymphocytes (Kono et al. 1990). A similar size (though less pronounced) CDNA was amplified from AtT-20 pituitary cells. Subsequently, as seen in Figure 2, two additional cDNAs were amplified using primers targeting areas of the intracytoplasmic region encoding intracellular domains of the receptor known to be involved in signal transduction processes by IL$2 R \beta$ in lymphocytes. These cDNAs amplified were the expected sizes of 508 and 345 base pairs, respectively, from both lymphocytes and AtT-20 pituitary cells. Experimental controls were used to ensure that the PCR- amplified DNA resulted from complementary mRNA, and was not the result of contamination from genomic DNA. These include the use of PCR primers spanning one or more introns, and the inability to amplify by PCR a detectable DNA band using purified mRNA that was treated with RNAse prior to reverse transcription (Kono et al. 1990; Shibuya et al. 1990). Subsequently, each of the three different PCR-generated cDNAs amplified from AtT-20 pituitary cells was subcloned, and three independent clones were sequenced for each of the three different cDNAs isolated. Sequence analysis showed that the nucleotide sequences of all three $\mathrm{CD}$ NAs, the one cDNA targeting the WSXWS motif (clone A) and the two intracytoplasmic cDNAs (clones B and C) from AtT-20 cells, were 100\% homologous with the corresponding segments of the murine lymphocyte IL$2 R \beta$. These three cDNA clones isolated from AtT-20 pituitary cells overlapped and corresponded to bps 410750 (clone A), bps 730-1238 (clone B), and bps 11821527 (clone C).

\section{Constitutive and CRF-Upregulated Expression of IL-2R $\beta$ mRNA in AtT-20 Pituitary Cells}

Ribonuclease protection analysis of AtT-20 pituitary cells was used to confirm the constitutive expression of IL-2R $\beta$ mRNA by AtT-20 pituitary cells and to determine whether the transcription of IL- $2 \mathrm{R} \beta$ by AtT- 20 pituitary corticotrophs could be modified by treatment with $10 \mathrm{nmol} / \mathrm{L}$ CRF. Figure 3 shows the results of a representative experiment (one of two independent experiments yielding similar results). As seen in Figure 3,

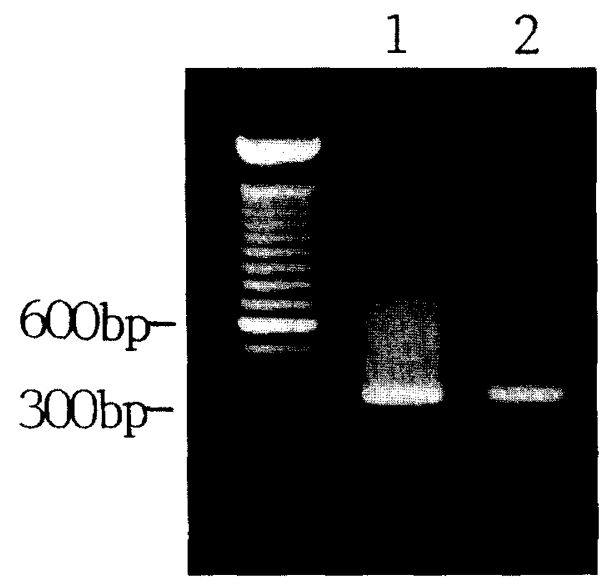

Figure 1. PCR amplification targeting regions of the transmembrane domain and the extracellular domain of IL-2R $\beta$ from AtT-20 pituitary cells, including the WSXWS motif characteristic of the cytokine receptor superfamily. This cDNA was subcloned and sequenced (clone A). The far left lane is the $100 \mathrm{bp}$ ladder. Lane 1: $341 \mathrm{bp}$ IL-2R $\beta$ cDNA from splenic lymphocytes. Lane 2: $341 \mathrm{bp}$ IL-2R $\beta$ cDNA from AtT20 pituitary cells (clone $\mathrm{A}$ ). 


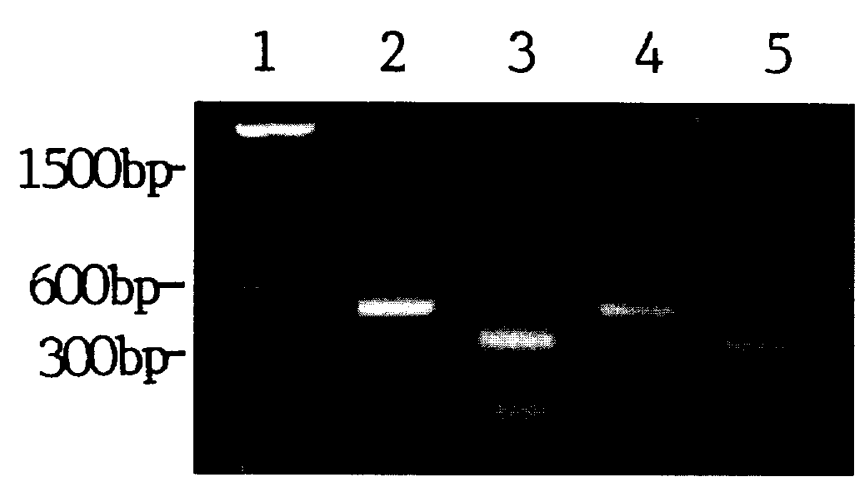

Figure 2. PCR amplification targeting the intracytoplasmic sequences of IL-2R $\beta$ from AtT-20 pituitary cells. These cDNAs were subcloned and sequenced (clone $\mathrm{A}$ and clone B). Lane 1: 100 bp DNA ladder. Lane 2: 5' 508 bp cDNA segment of the intracytoplasmic domain of IL-2R $\beta$ from splenic lymphocytes. Lane 3: 3' 345 bp cDNA segment of the intracytoplasmic domain of IL-2R $\beta$ from splenic lymphocytes. Lane 4: 5' 508 bp cDNA segment of the intracytoplasmic domain of IL-2R $\beta$ from AtT-20 pituitary cells (clone B). Lane 6: 3' 345 bp cDNA segment of the intracytoplasmic domain of IL-2R $\beta$ from AtT-20 pituitary cells (clone C).

ribonuclease protection analysis showed that unstimulated AtT-20 pituitary cells constitutively express IL$2 \mathrm{R} \beta$, though at considerably lower levels than murine splenic lymphocytes stimulated by ConA. Compared to unstimulated AtT-20 pituitary cells, treatment of AtT-20 cells with $10 \mathrm{nM} \mathrm{CRF}$ for $24 \mathrm{~h}$ produced a modest increase in IL-2R $\beta$ mRNA. Scanning densitometry of autoradiograms showed that the level of IL-2R $\beta$ mRNA expressed by CRF stimulated AtT-20 cells was approximately two times higher than unstimulated AtT-20 cells.

\section{Species-Specific IL-2 Induces Intracellular Signals in AtT-20 Pituitary Cells Ascribed to IL-2R $\beta$}

Since IL-2R $\beta$ is essential to aspects of IL-2-induced intracellular signal transduction including the transcrip-

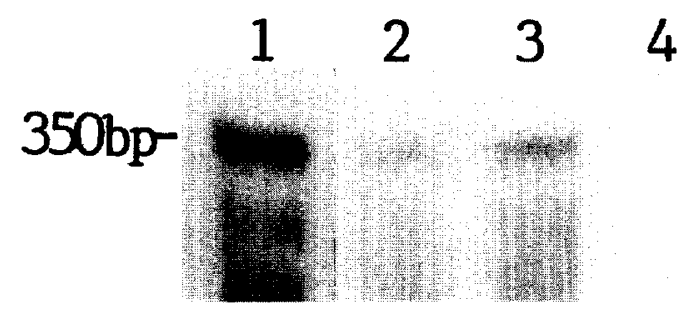

Figure 3. Autoradiogram of ribonuclease protection analysis of IL-2R $\beta$ mRNA from unstimulated and CRF stimulated AtT-20 pituitary cells. Lane 1: IL-2R $\beta$ cDNA from ConA stimulated murine (Balb/c) splenic lymphocytes. Lane 2: IL-2R $\beta$ cDNA from AtT-20 pituitary cells cultured in media only (unstimulated) for $24 \mathrm{~h}$. Lane 3: IL-2R $\beta$ cDNA from AtT-20 pituitary cells treated with $10 \mathrm{nmol} / \mathrm{L} \mathrm{CRF}$ for $24 \mathrm{~h}$. Lane 4 : tRNA control. tion of nuclear proto-oncogenes, we sought to determine whether mIL-2 could induce c-myc mRNA expression by AtT-20 murine pituitary cells. As depicted in Figure 4, mIL-2-induced transient expression of c-myc message with the highest level expressed after $60 \mathrm{~min}$ of mIL-2 stimulation.

Another function mediated by IL-2R $\beta$ in subsets of lymphocytes is the transduction of a growth signal induced by IL-2. Figure 5 depicts the results of experiments examining the ability of mIL-2 to deliver a DNA replication signal (measured by ${ }^{3} \mathrm{H}$-thymidine incorporation) in AtT-20 pituitary cells. As seen in Figure 5, mIL-2 produced a dose-dependent increase in $\left[{ }^{3} \mathrm{H}\right]$ thymidine incorporation $[\mathrm{F}(3,35)=4.8, p<.01]$ with the 10 $\mathrm{nmol} / \mathrm{L}$ concentration being significantly different than baseline control levels (media only) $(p<.01)$. Heat-inactivated mIL-2 had no effect on AtT-20 cell proliferation (data not shown).

Figure 6 shows the results of subsequent experiments to determine if this mIL-2-induced DNA replication in AtT-20 cells could be blocked or antagonized by a monoclonal antibody to the murine lymphocyte IL$2 \mathrm{R} \beta$. In preliminary experiments, AtT-20 cells were cultured at various concentrations of the anti-mIL2R $\beta$ monoclonal antibody, and the integrity of the cells was
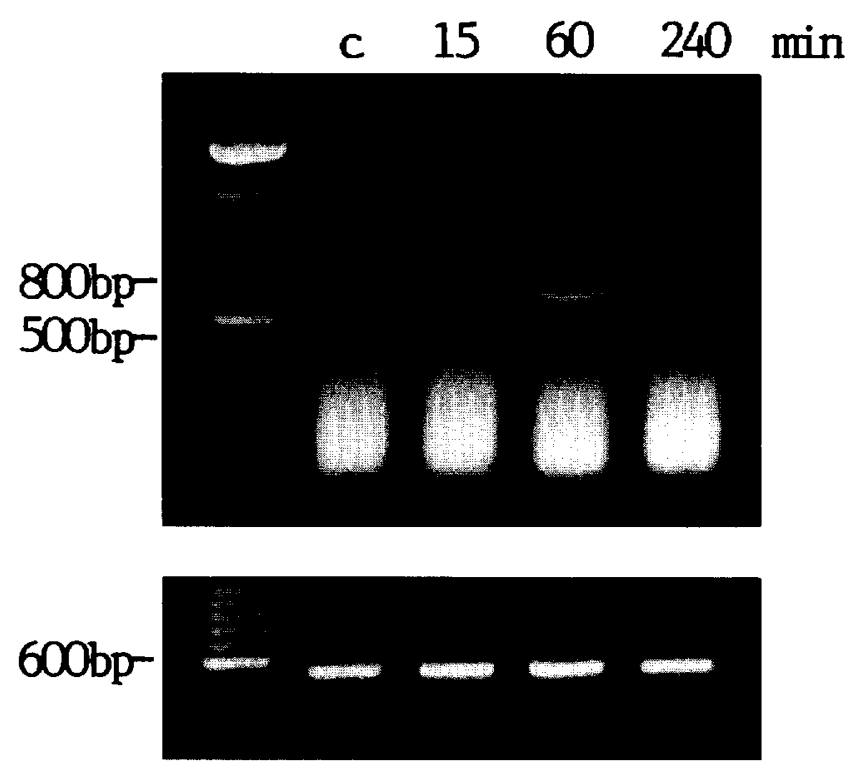

Figure 4. Induction of c-myc nuclear proto-oncogene gene expression in AtT-20 pituitary cells by mIL-2. AtT-20 pituitary cells were cultured in the presence of $1 \mathrm{nmol} / \mathrm{L} \mathrm{mIL-2}$ for various times. The upper panel represents PCR analysis of c-myc gene expression (776 bp) and the lower panel for $\beta$-actin $(540 \mathrm{bp})$. The far left lane is the $100 \mathrm{bp}$ ladder. The lane labeled $c$ represents the control (AtT-20 cells cultured in media only for $60 \mathrm{~min}$ ) for AtT-20 cells stimulated with $\mathrm{mIL}-2$ for $60 \mathrm{~min}$, the time point where the highest level of c-myc gene expression was detected. 


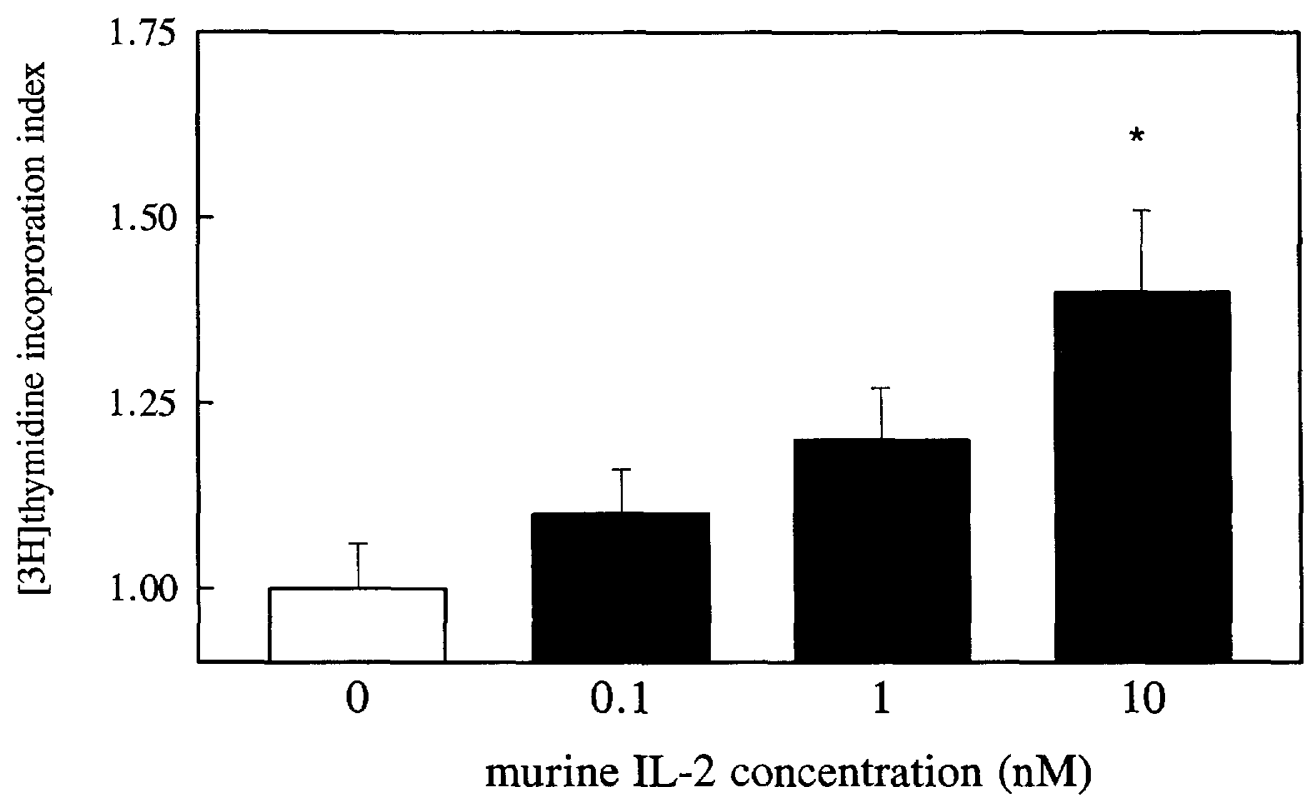

Figure 5. IL-2-induced DNA replication in murine AtT-20 pituitary cells. AtT-20 pituitary cells were cultured in the presence of various concentrations of murine recombinant IL-2 (mIL-2) and $[\mathrm{H}$ ] thymidine incorporation was measured. Data are ex-pressed as the $\left[{ }^{3} \mathrm{H}\right]$ thymidine incorporation index (the ratio of $\left[{ }^{3} \mathrm{H}\right]$ incorporation in the presence of $\mathrm{mIL}-2 /\left[{ }^{3} \mathrm{H}\right]$ thymidine in-corporation in the absence of $\mathrm{mLL}-2$ ). Each bar represents the mean $\pm \mathrm{SEM}$ of nine cultures. Analysis of variance (ANOVA) demonstrated a significant main effect of mIL- 2 concentration. $p<.01$ compared to control (conc. 0 ).

subsequently examined by trypan blue exclusion (Petitto et al. 1989). Based on these results and the immunological literature, a concentration of $0.05 \mu \mathrm{g} / \mathrm{ml}$ culture of the anti-IL2R $\beta$ monoclonal antibody was selected for these experiments (higher concentrations of the antibody cultured alone with AtT-20 cells were found to significantly inhibit basal $\left[{ }^{3} \mathrm{H}\right]$ thymidine incorporation). As can be seen (Figure 6), the anti-mIL2R $\beta$ monoclonal partially antagonized (by about one-half) the mIL-2induced increase in $\left[{ }^{3} \mathrm{H}\right]$ thymidine incorporation. This antagonism, however, was not statistically significant. In wells where AtT-20 pituitary cells were cultured in the presence of the anti-mIL2R $\beta$ alone (not shown), there was marked variability on $\left[{ }^{3} \mathrm{H}\right]$ thymidine incorporation that overlapped significantly with each of the three conditions tested in Figure $6(n=10$ cultures, mean \pm SEM, $1.67 \pm 0.34$, overall appearing to have a growth-enhancing effect).

\section{DISCUSSION}

This study demonstrated the IL-2R $\beta$ gene is expressed by AtT-20 pituitary cells. Together, the three overlap-

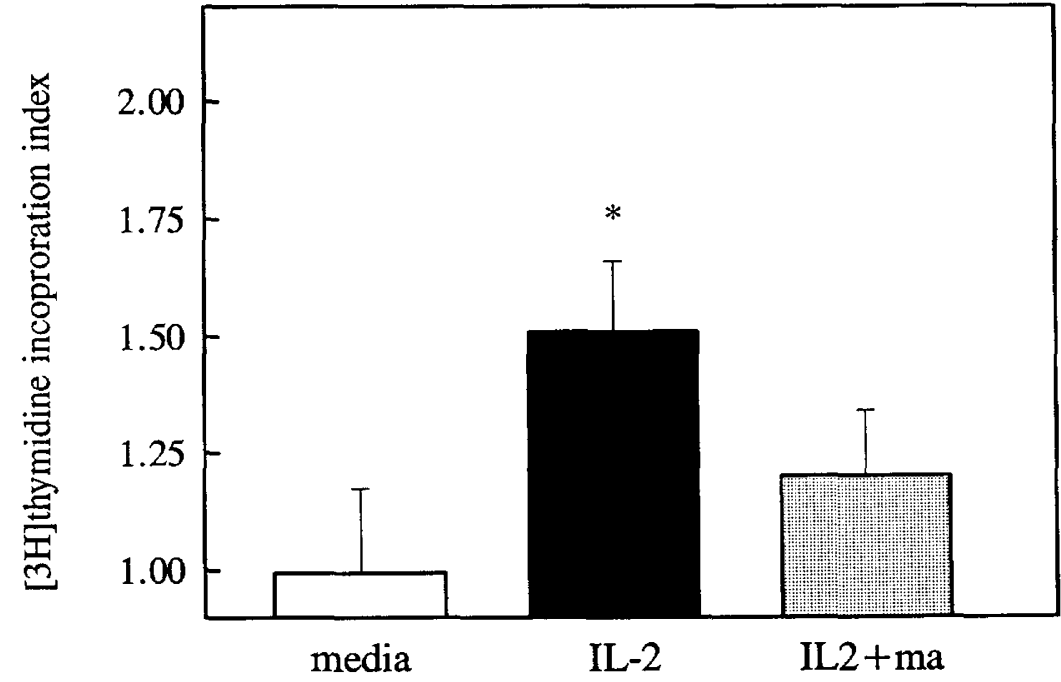

Figure 6. Antagonism of IL-2-induced DNA replication in murine AtT-20 pituitary cells by an anti-mIL2R $\beta$ monoclonal antibody. AtT-20 cells cultured in the presence of $10 \mathrm{nmol} / \mathrm{L} \mathrm{mIL-2}$ were pretreated with antimIL2R $\beta$ monoclonal antibody. Each bar represents the mean \pm SEM of 9-10 cultures. ${ }^{*}$ Level of $\left[{ }^{3} \mathrm{H}\right]$ thymidine incorporation significantly different $(p<.05)$ from the level of $\left[{ }^{3} \mathrm{H}\right]$ thymidine incorporation by At $\mathrm{T}-20$ cells cultured in media only. 
ping CDNAs that were isolated and sequenced from AtT-20 pituitary cells coincided with bp 410-1527 (approximately $70 \%$ of the full-length coding sequence) of the mouse lymphocyte IL-2R $\beta$. The nucleotide sequence of these three IL-2R $\beta$ cDNA clones from AtT-20 cells were identical to the lymphocyte IL-2R $\beta$ nucleotide sequence. Clone A (bps 410-750) comprised the most proximal segment of the transmembrane domain and most of the extracellular domain of the receptor, including the WS motif (WSXWS sequence) characteristic of the cytokine receptor superfamily (Bazan 1990; Taniguchi and Minami 1993). Interestingly, this highly conserved region is also shared by two classic endocrine receptors, growth hormone and prolactin (Bazan 1990), and this same gene sequence is also expressed in the mouse forebrain including limbic areas (e.g., hippocampus) known to modulate the activity of the HPA axis (Petitto and Huang 1994). Clone B (bps 730-1238) and clone $C$ (bps 1182-1527) contain nucleotide sequences of the intracytoplasmic domain of IL-2R $\beta$ including the Src and JAK family homology domains of nonreceptor protein tyrosine kinases, which are known to be essential for some of the complex signaling processes activated by IL-2 in lymphocytes. Many cytokine receptors on immune cells, including the IL-2 receptors, are typically multisubunit receptors comprised of subunits that may combine via differential expression to form different functional subtypes (e.g., high versus intermediate IL-2 receptors). Some cytokine receptors share common subunits with one another (e.g., IL-2Ry is a common $\gamma$ subunit for lymphocyte IL-4 and IL-7 receptors) (Kondo et al. 1993; Noguchi et al. 1993). Although certain classic neurotransmitter receptors exist as receptor "isoforms" derived from the same gene by alternative RNA splicing (e.g., the $\mathrm{D}_{2}$ dopamine receptor has long and short isoforms), this is not the case for the lymphocyte IL-2 receptor heterotrimer complex (Minami et al. 1993). Thus, based on our finding that the sequences of the IL-2R $\beta$ clones isolated from AtT-20 pituitary cells comprised more than two-thirds of the coding sequence and were identifical to the corresponding lymphocyte IL-2R $\beta$ sequences, it is highly likely that the remainder of the gene coding sequence expressed by AtT-20 pituitary cells is the same as the lymphocyte. Nonetheless, the possibility that the remaining areas of IL-2R $\beta$ expressed by AtT-20 pituitary cells are different from the lymphocytes sequences cannot be ruled out. This is the first demonstration, to our knowledge, that intracytoplasmic sequences of the receptor known to be critical for IL-2 signaling have been cloned and sequenced from a nonimmune tissue. In the immune system, subpopulations of lymphocytes (e.g., natural killer cells, subsets of $\mathrm{C}^{+} \mathrm{T}$ cells) constitutively express IL-2R 3 (Sigel et al. 1987; Takeshita et al. 1992). Our data also show that AtT-20 pituitary cells constitutively expressed IL-2R $\beta$ and that upon stimulation of these corticotrophs with CRF, IL-2R $\beta$ gene transcription is increased about two-fold.

Although IL-2 has been shown to induce ACTH secretion from pituitary cells including AtT-20 cells, the direct effects of species-specific IL-2 on intracellular signaling in AtT-20 pituitary cells had not been established. Thus, since IL-2R $\beta$ is known to be essential for transducing intracellular signals by IL-2 in lymphocytes, we determined if this pituitary cell line, which constitutively expresses IL-2R $\beta$, was capable of IL-2 mediated signaling events. These experiments revealed that mIL-2 treatment of AtT-20 cells produced a transient increase in the transcription of the gene for c-myc nuclear protooncogene. In lymphocytes, both the intracytoplasmic serine-rich and acidic region of IL-2R $\beta$ (AtT-20 clones B and C) are critical for IL-2-mediated induction of some nuclear proto-oncogene transcriptional regulators (e.g., c-myc, c-fos, c-jun) and the proliferative response (Roussel et al. 1991; Shibuya et al. 1992; Satoh et al. 1992; Taniguchi 1995). A number of important questions remain to be determined regarding whether the complex profile of IL-2R $\beta$-mediated signaling events in pituitary cells parallels or differs from signaling processes in lymphocytes. Since the time course of this transient increase in c-myc coincidences with the time course of IL-2-induced ACTH release found in rodent pituitary cells in vitro and in vivo observed in some previous studies (Smith et al. 1989; Naito et al. 1989), it will be of interest to determine if this transcription factor is involved in the control of IL-2-induced ACTH secretion by AtT-20 pituitary cells.

The present study demonstrated further that mIL-2induced a dose-dependent DNA replication signal to AtT-20 pituitary cells. Though not a focus of this investigation, parametric studies optimizing the various culture conditions (e.g., pulse time, cell density, media constituents) could increase further the magnitude of the DNA replication signal by IL-2 (e.g., at $10 \mathrm{nmol} / \mathrm{L}$ ) that we have observed. In the present study, the increased DNA replication signal to AtT-20 pituitary cells was induced by $10 \mathrm{nmol} / \mathrm{L}$ IL-2 (but was not delivered by the same concentration of the heat-inactivated mIL-2) and could be partially antagonized by the addition of an anti-IL2R $\beta$ monoclonal antibody. This anti-IL2R $\beta$ monoclonal antibody (clone TM- $\beta 1$ ) is, to our knowledge, the only one available for the mouse. It has been found to exhibit varied and bidirectional effects on growth responses in different IL-2R $\beta$-bearing immune cell lines (Hatakeyama et al. 1989a). Pretreatment of these pituitary cell cultures with the anti-IL2R $\beta$ monoclonal antibody resulted in approximately a $50 \%$ reduction of the magnitude of the IL-2 effect. Unfortunately, as noted earlier, since higher concentrations of the antibody alone appeared to have direct toxic effect on AtT20 cells in culture, it precluded our ability to reliably attain complete and unequivocal blockade of the IL-2 
effect. Future experiments will require a different antiIL2R $\beta$ monoclonal antibody as well as benefit from additional controls (e.g., an isotype, subclass, and lightchain matched antibody to an antigen not expressed by AtT-20 cells) and an endocrine cell line with growth characteristics more amenable to such manipulations (e.g., cells with a shorter doubling time, cells that grow in monolayers rather than clusters).

In summary, the present experiments confirmed the hypothesis that IL-2R $\beta$ is constitutively expressed by AtT-20 pituitary cells and involved in mediating intracellular signal transduction processes induced by species-specific IL-2 in this endocrine cell line. These functions comprise two signaling parameters that have been previously ascribed to IL-2R $\beta$ in lymphocytes. It will be important to determine in future investigations whether endocrine cells also express an IL2R $y$ (or IL2R $\gamma$ like) subunit, which may also be constitutively expressed together with IL-2R $\beta$ and involved in the complex array intracellular signaling events induced by IL-2 (Takeshita et al. 1992; Minami et al. 1993; Taniguchi and Minami 1993; Taniguchi 1995). Knowledge of the mechanisms by which IL-2 mediates intracellular signaling processes in pituitary and brain cells could provide better understanding of the molecular basis of altered HPA function in certain neuroendocrinological and major neuropsychiatric disorders.

\section{ACKNOWLEDGMENTS}

This work was presented in part at the 1995 Annual Meeting of the American College of Neuropsychopharmacology and was supported by National Institutes of Health Grant NS343623 (JMP).

\section{REFERENCES}

Araujo DM, Lapchak PA (1994): Induction of immune system mediators in the hippocampal formation in Alzheimer's and Parkinson's diseases: Selective effects on specific interleukins and interleukin receptors. Neuroscience 61:745-754

Arzt E, Stelzer G, Renner U, Lange M, Muller OA, Stalla GK (1992): Interleukin-2 and interleukin-2 receptor expression in human corticotrophic adenoma and murine pituitary cell cultures. J Clin Invest 90:1944-1951

Ausubel FM, Brent R, Kingston RE, Moore DD, Seidmann JG, Smith JA, Struhl K (eds) (1995): Current Protocols in Molecular Biology. New York, Greene Publishing Associates and Wiley-Interscience

Bartholomew SA, Hoffman SA (1993): Effects of peripheral cytokine injections on multiple unit activity in the anterior hypothalamic area of the mouse. Brain Behav Immunol 7:301-316
Bazan JF (1990): Structural design and molecular evolution of a cytokine receptor superfamily. Proc Natl Acad Sci USA 87:6934-6938

Bindoni M, Perciavalle V, Berretta S, Belluardo N, Diamantstein $T$ (1988): Interleukin-2 modifies the bioelectric activity of some neurosecretory nuclei in the rat hypothalamus. Brain Res 462:10-14

Brown SL, Smith LR, Blalock JE (1987): Interleukin-1 and interleukin-2 enhance proopiomelanocortin gene expression in pituitary cells. J Immunol 139:3181-3183

Cambronero JC, Rivas FJ, Borrell J, Guaza C (1992): Interleukin-2 induces corticotrophin-releasing hormone release from superfused rat hypothalami: Influence of glucocorticoids. Endocrinology 131:677-683

Denicoff KD, Durkin TM, Lotze MT, Quinlan PE, Davis CL, Listwick SJ, Rosenberg SA, Rubinow DR (1989): The neuroendocrine effects of interleukin-2 treatment. J Clin Endocrinol Metab 69:402-410

Farrar WL (1984): Endorphin modulations of lymphokine activity. In Fraioli F, Isidori A, Mazzetti M (eds), Opioid Peptides in the Periphery. Amsterdam, Elsevier, pp 159-165

Hanisch U-K, Rowe W, Sharma S, Meaney MJ, Quirion R (1994): Hypothalamic-pituitary-adrenal activity during chronic central administration of interleukin-2. Endocrinology 135:2465-2471

Harbuz MS, Stephanou A, Knight RA, Chover Gonzalez AJ, Lightman SL (1992): Action of interleukin-2 and interleukin- 4 on CRF mRNA in the hypothalamus and POMC mRNA in the anterior pituitary. Brain Behav Immunol 6:214-222

Hatakeyama M, Hishashi M, Takeshi D, Taniguchi T (1989a): A restricted cytoplasmic region of IL-2 receptor $\beta$ chain is essential for growth signal transduction but not for ligand binding and internalization. Cell 59:837-845

Hatakeyama M, Tsudo M, Minamoto S, Kono T, Doi T, Miyata T, Miyasaka M, Taniguchi T (1989b): Interleukin-2 receptor $\beta$ chain gene: Generation of three receptor forms by cloned human $\alpha$ and $\beta$ chain cDNAs. Science 244:551-556

Hillhouse EW (1994): Interleukin-2 stimulates the secretion of arginine vasopressin but not corticotrophin-releasing hormone from rat hypothalamic cells in vitro. Brain Res 650:323-325

Karanth S, McCann SM (1991): Anterior pituitary hormone control by interleukin-2. Proc Natl Acad Sci USA 88:2961-2965

Karanth S, Aguila MC, McCann SM (1993): The influence of interleukin-2 on the release of somatostatin and growth hormone-releasing hormone by mediobasal hypothalamus. Neuroendocrinology 58:185-190

Kondo M, Takeshita T, Ishii N, Nakamura M, Watanabe S, Arai K, Sugamura K (1993): Sharing of the interleukin-2 (IL-2) receptor $\gamma$ chain between receptors for IL-2 and IL-4. Science 262:1874-1877

Kono T, Doi T, Yamada G, Hatakeyama M, Minamoto S, Tsudo M, Miyasaka M, Miyata T, Taniguchi T (1990): Murine interleukin-2 receptor $\beta$ chain: Dysregulated gene expression in lymphoma line EL-4 caused by a promoter insertion. Proc Natl Acad Sci USA 87:18061810 
Lapchak PA, Araujo DM (1993): Interleukin-2 regulates monoamine and opioid peptide release from the hypothalamus. Neuroreport 4:303-306

Licinio J, Seibyl JP, Altemus M, Charney DS, Krystal JH (1993): Elevated CSF levels of interleukin-2 in neuroleptic-free schizophrenic patients. Am J Psychiatry 150: 1408-1410

Lotze MT, Frana LW, Sharrow SO, Robb RJ, Rosenberg, SA (1985): In vivo administration of purified human interleukin-2. I. Half-life and immunologic effects of the Jurkat cell line-derived interleukin-2. J. Immunol 134:157166

Maes M, Bosmans E, Suy E, Vanderorest C, Dejonckheere C, Raus J (1991): Antiphospholipid, antinuclear, EpsteinBarr and cytomegalovirus antibodies, and soluble interleukin-2 receptors in depressive patients. J Affect Disord $2^{1}: 133-140$

Maes M, Bosmans E, Calabrese J, Smith R, Meltzer HY (1995): Interleukin-2 and interleukin-6 in schizophrenia and mania: Effects of neuroleptics and mood stabilizers. J Psychiat Res 29:141-152

McAllister CG, van-Kammen DP, Rehn TJ, Miller AL, Gurklis J, Kelley ME, Yao J, Peters JL (1995): Increases in CSF levels of interleukin-2 in schizophrenia: Effects of recurrence of psychosis and medication status. Am J Psychiatry 152:1291-1297

Merrill JE (1990): Interleukin-2 effects in the central nervous system. Ann NY Acad Sci 594:188-199

Minami Y, Kono T, Miyazaki T, Taniguchi T (1993): The IL-2 receptor complex: Its structure, function, and target genes. Annu Rev Immunol 11:245-268

Naito Y, Fukata J, Tominaga T, Masui Y, Hirai Y, Murakami N, Tamai S, Mori K, Imura H (1989): Adrenocorticotropic hormone-releasing activities of interleukins in a homologous in vivo system. Biochem Biophys Res Commun 164:1262-1267

Nelson BH, Lord JD, Greenberg PD (1994): Cytoplasmic domains of the interleukin-2 receptor $\beta$ and $\gamma$ chains mediate the signal for $\mathrm{T}$-cell proliferation. Nature 369:333-336

Nimgaonkar VL, Yang ZW, Zhang JS, Brar A, Chakravarti, Ganguli R (1995): Association study of schizophrenia and the interleukin-2 receptor $\beta$ chain gene. Am J Med Genet 60:448-451

Nistico G (1993): Communications among central nervous system, neuroendocrine, and immune systems. Prog Neurobiol 40:463-475

Nistico G, De Sarro G (1991): Is interleukin-2 a neuromodulator in the brain? Trends Neurosci 14:146-150

Noguchi M, Nakamura Y, Russell SM, Ziegler SF, Tsang M, Cao X, Leonard WJ (1993): Interleukin-2 receptor $\gamma$ chain: A functional component of the interleukin-7 receptor. Science 262:1877-1880

Otero GC, Merrill JE (1995): Molecular cloning of IL-2R $\alpha$, IL$2 \mathrm{R} \beta$, and IL-2R $\gamma$ cDNA from a human oligodendroglioma cell line: presence of IL-2R mRNAs in the human central nervous system. Glia 14:295-302

Ottaviani E, Franchini A, Caselgrandi E, Cossarizza A, Franceschi, C (1994): Relationship between corticotro- pin-releasing factor and interleukin-2: Evolutionary evidence. FEBS Lett 351:19-21

Petitto JM, Skolnick P, Arora PK (1989): Suppression of natural killer cell activity by FG 7142, a benzodiazepine receptor "inverse agonist." Brain Behav Immunol 3:39-46

Petitto JM, Huang Z (1994): Molecular cloning of a partial cDNA of the interleukin- 2 receptor- $\beta$ in normal mouse brain: In situ localization in the hippocampus and expression by neuroblastoma cells. Brain Res 650:140145

Petitto JM, Huang Z (1995): Molecular cloning of the coding sequence of an interleukin-2 receptor $\alpha$ subunit cDNA in murine brain. J Neuroimmunol 59:135-141

Petitto JM, Huang Z, McCarthy DB (1994): Molecular cloning of NPY-Y1 receptor cDNA from rat splenic lymphocytes: Evidence of low levels of mRNA expression and [125I] NPY binding sites. J Neuroimmunol 54:81-86

Quirion R, Araujo DM, Lapchak PA, Seto D, Chabot JG (1991): Growth factors and lymphocytes: Modulators of cholinergic neuronal activity Can J Neurol Sci 18:390393

Raber J, Bloom FE (1994): IL-2 induces vasopressin release from the hypothalamus and the amygdala: Role of nitric oxide-mediated signaling. J Neurosci 14:6187-6195

Raber J, Koob GF, Bloom FE (1995): Interleukin-2 (IL-2) induces corticotrophin-releasing factor (CRF) release from the amygdala and involves nitric-oxide mediated signaling: Comparison with the hypothalamic response. J Pharmacol Exp Ther 272:815-824

Rapaport MH, Torrey EF, McAllister CG, Nelson DL, Pickar D, Paul SM (1993): Increased serum soluble interleukin-2 receptors in schizophrenic monozygotic twins. Eur Arch Psychiatry Clin Neurosci 243:7-10

Roussel MF, Cleveland JL, Shurtleff SA, Sherr CJ (1991): Myc rescue of mutant CSF-1 receptor impaired in mitogenic signaling. Nature 353:361-363

Satoh T, Minami Y, Kono T, Yamada K, Kawahara A, Taniguchi T, Kaziro Y (1992): Interleukin 2-induced activation of Ras requires two domains of interleukin 2 receptor $\beta$ subunit, the essential region of growth stimulation and Lck-binding domain. J Biol Chem 267:2542325427

Sauer J, Stalla GK, Muller OA, Arzt E (1994): Inhibition of interleukin-2-mediated lymphocyte activation in patients with Cushing's syndrome: A comparison with hypocortisolemic patients. Neuroendocrinology 59:144-151

Shibuya H, Yoneyama M, Nakamura Y, Harada H, Hatakeyama M, Minamoto S, Kono T, Doi T, White R, Taniguchi T (1990): The human interleukin-2 receptor $\beta$-chain gene: Genomic organization, promoter analysis and chromosomal assignment. Nucl Acids Res 18:3697-3703

Shibuya H, Yoneyama M, Ninomiya-Tsuji J, Matsumto K, Taniguchi T (1992): IL-2 and EGF receptors stimulate the hematopoietic cell cycle via different signaling pathways: Demonstration of a novel role for c-myc. Cell 70:57-67

Sigel JP, Sharon M, Smith PL, Leonard WJ (1987): The IL-2 receptor $\beta$ chain ( $p 70)$ : Role in mediating signals for LAK, NK, and proliferative activities. Science 238:75-78 
Smith LR, Brown SL, Blalock JE (1989): Interleukin-2 induction of ACTH secretion: Presence of an interleukin-2 receptor alpha-chain-like molecule on pituitary cells. J Neuroimmunol 21:249-254

Takeshita T, Asao H, Ohtani K, Ishii N, Kumaki S, Tanaka N, Munakata H, Nakamura M, Sugamura K (1992): Clon- ing of the $\gamma$ chain of the human IL-2 receptor. Science 257:379-382

Taniguchi T (1995): Cytokine signaling through nonreceptor protein tyrosine kinases. Science 268:251-255

Taniguchi T, Minami Y (1993): The IL-2/IL-2 receptor system: A current overview. Cell 73:5-8 